\title{
Carotid artery stenting with optical coherence tomography
}

Naif M. Alotaibi, MD, Francesca Sarzetto, MD, Joel Ramjist, and

Victor X.D. Yang, MD, PhD

Neurology ${ }^{\circledR}$ 2018;90:384-385. doi:10.1212/WNL.0000000000005003

\section{Correspondence}

Dr. Yang

Victor.Yang@sunnybrook.

ca

Figure 1 Postoperative findings

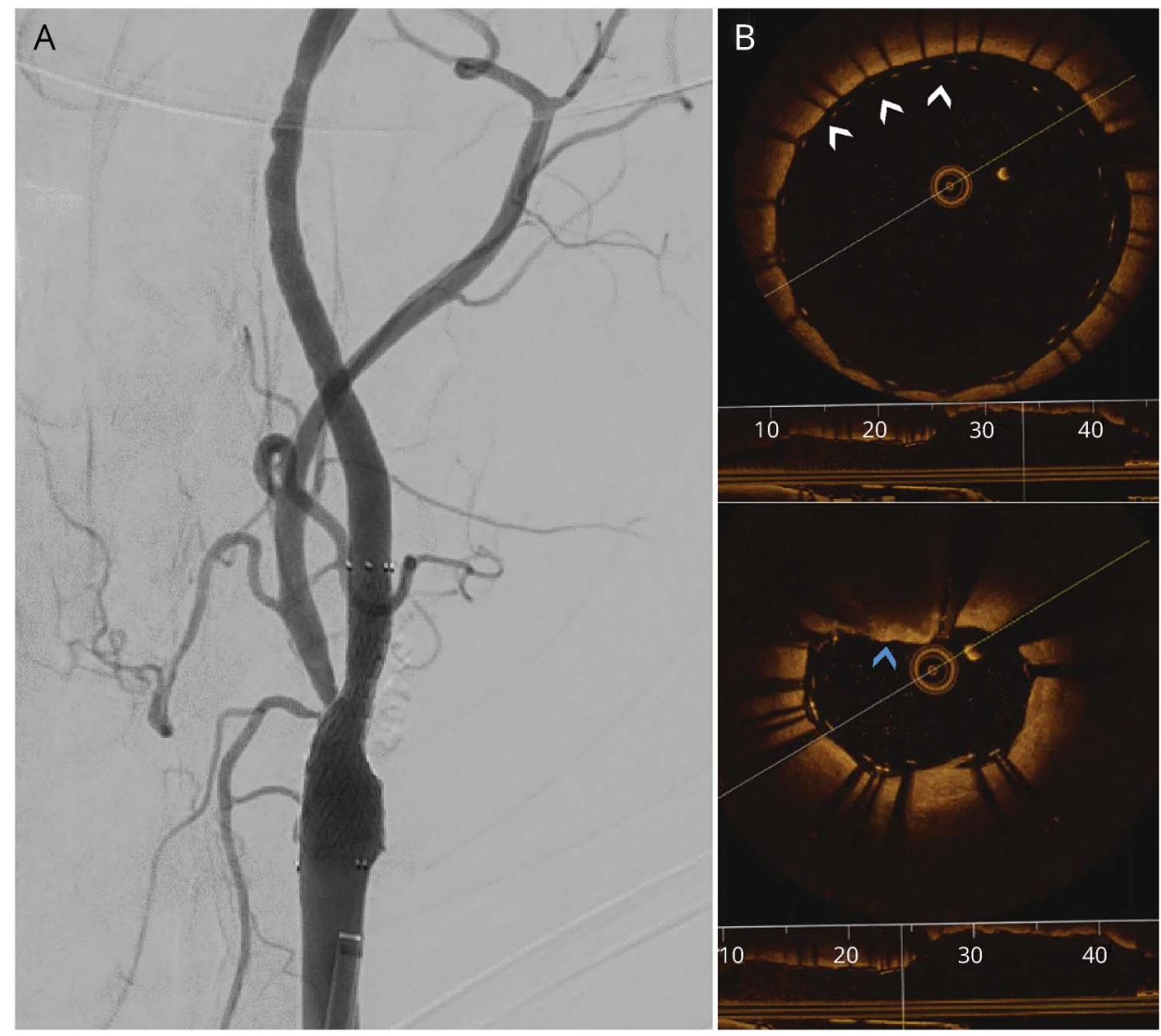

(A) Satisfactory poststent angiography without filling defect detected. (B) Two endoluminal cross-sectional optical coherence tomography images demonstrate the absence of any plaque protrusions within the stent struts (white arrowheads) and plaque protrusion between the stent struts (blue arrowhead) at a different zone.

A 61-year-old man underwent a left cervical internal carotid artery stenting following a recent ischemic stroke. Postoperative angiography was satisfactory and did not reveal any in-stent filling defect (figure 1A). Optical coherence tomography (OCT) probe was used to visualize the endoluminal area following stenting. OCT confirmed optimum placement of the stent and reveled a small plaque protrusion from the stent struts following deployment (figure 1B). 
Figure 2 3D reconstruction

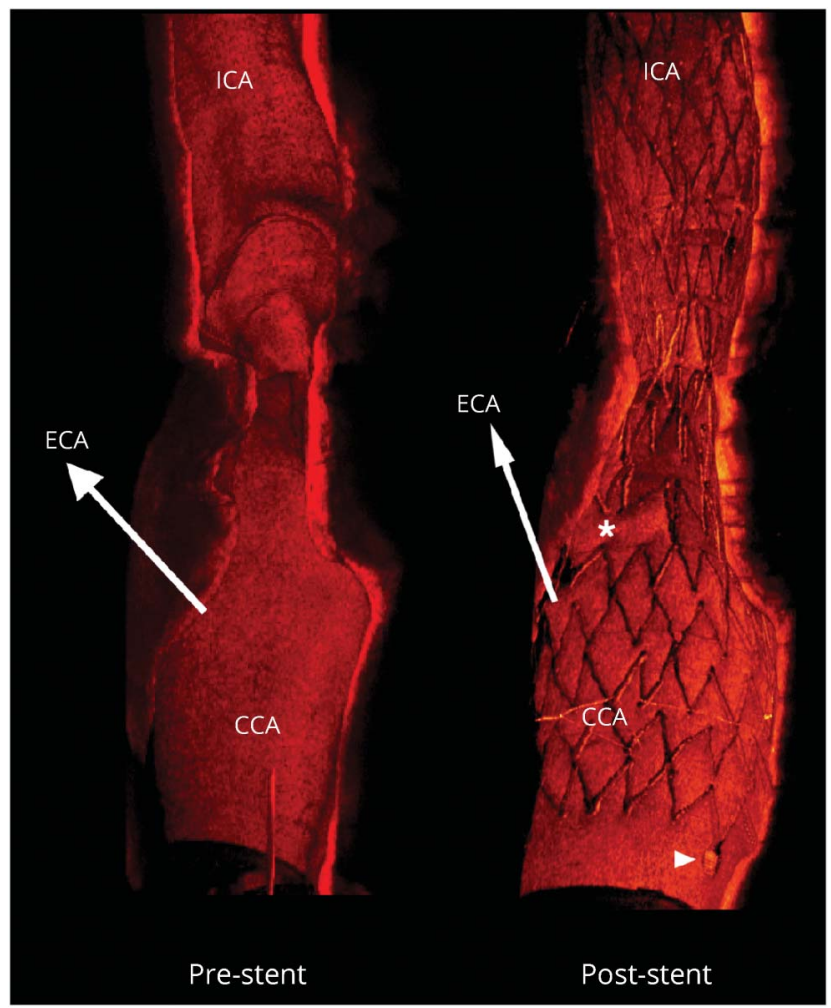

$3 \mathrm{D}$ reconstruction of the left cervical internal carotid artery using optical coherence tomography images before and after stenting. Plaque protrusion between the stent struts is marked with asterisk and arrowhead. CCA = common carotid artery; ECA = external carotid artery; ICA = internal carotid artery.
OCT offers the advantage of obtaining very high spatial resolution in real time of the artery lumen (figure 2). OCT can be a useful adjunct to diagnose in-stent plaque protrusions that are difficult to visualize in digital subtraction angiography. ${ }^{1,2}$

\section{Author contributions}

Conception and design, acquisition of data, analysis and interpretation of data: All authors. Drafting the article: Drs. Alotaibi and Yang. Critically revising the article: Dr. Yang. Approved the final version of the manuscript on behalf of all authors: Dr. Yang.

\section{Study funding}

No targeted funding reported.

\section{Disclosure}

The authors report no disclosures relevant to the manuscript. Go to Neurology.org/ $\mathrm{N}$ for full disclosures.

\section{References}

1. Fujimoto JG, Pitris C, Boppart SA, Brezinski ME. Optical coherence tomography: an emerging technology for biomedical imaging and optical biopsy. Neoplasia 2000;2: $9-25$.

2. Kotsugi M, Takayama K, Myouchin K, et al. Carotid artery stenting: investigation of plaque protrusion incidence and prognosis. JACC Cardiovasc Interv 2017;10: 824-831.

\section{Share Your Artistic Expressions in Neurology 'Visions'}

AAN members are urged to submit medically or scientifically related artistic images, such as photographs, photomicrographs, and paintings, to the "Visions" section of Neurology ${ }^{\bullet}$. These images are creative in nature, rather than the medically instructive images published in the NeuroImages section. The image or series of up to six images may be black and white or color and must fit into one published journal page. Accompanying description should be 100 words or less; the title should be a maximum of 96 characters including spaces and punctuation.

Please access the Author Center at NPub.org/authors for full submission information. 


\title{
Neurology
}

\section{Carotid artery stenting with optical coherence tomography \\ Naif M. Alotaibi, Francesca Sarzetto, Joel Ramjist, et al. \\ Neurology 2018;90;384-385 \\ DOI 10.1212/WNL.0000000000005003}

This information is current as of February 19, 2018

\author{
Updated Information \& \\ Services \\ including high resolution figures, can be found at: \\ http://n.neurology.org/content/90/8/384.full \\ References \\ This article cites 2 articles, 1 of which you can access for free at: \\ http://n.neurology.org/content/90/8/384.full\#ref-list-1 \\ Subspecialty Collections \\ This article, along with others on similar topics, appears in the \\ following collection(s): \\ All Cerebrovascular disease/Stroke \\ http://n.neurology.org/cgi/collection/all_cerebrovascular_disease_strok \\ Permissions \& Licensing \\ Information about reproducing this article in parts (figures,tables) or in \\ its entirety can be found online at: \\ http://www.neurology.org/about/about_the_journal\#permissions \\ Reprints \\ Information about ordering reprints can be found online: \\ http://n.neurology.org/subscribers/advertise
}

Neurology $®$ is the official journal of the American Academy of Neurology. Published continuously since 1951 , it is now a weekly with 48 issues per year. Copyright @ 2018 American Academy of Neurology. All rights reserved. Print ISSN: 0028-3878. Online ISSN: 1526-632X.

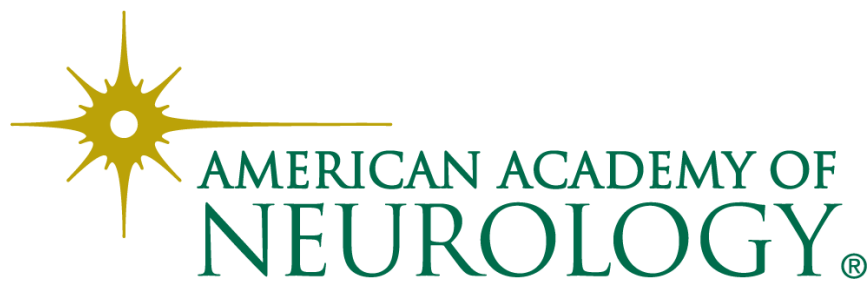

